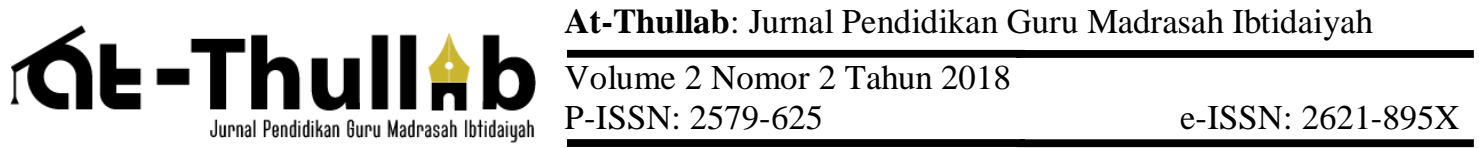

\section{PENGARUH GEOGRAFIS KEHIDUPAN MASYARAKAT SUKU SAMIN DI KABUPATEN BOJONEGORO SEBAGAI PEMBELAJARAN IPS MATERI KERAGAMAN BUDAYA}

\author{
Ita Aristia Sa'ida \\ Universitas Nahdlatul Ulama Sunan Giri Bojonegoro \\ e-mail: itaaristia@unugiri.ac.id
}

\begin{abstract}
The Samin community which has various traditions and cultures can be categorized as one of the ethnic groups in Indonesia. The Samin community is a group of people who follow the Samin Surosentiko teachings that emerged during the Dutch colonial period. As one of the ethnic groups in Indonesia, the Samin community has cultural values that are different from other communities. For more than 100 years the Samin people have experienced changes in the social and cultural institutions that they have been following. Samin community life is influenced by the geographical conditions of the area where they live. So what they do must have something to do with the nature where they live. This research was conducted at the Samin community in Japanese Village, Margomulyo Sub-district, Bojonegoro District, using descriptive qualitative research. the analysis process will be carried out using an interactive analysis model (Miles and Huberman in Sutopo, 2002). In this analysis model, the three components of the analysis are: data reduction, data presentation, and drawing conclusions or verification. So the results obtained in this study are to know the ability of the Samin community to interact with the environment and nature that deserves to be appreciated. The Samin community in its development has gone through various kinds of pressures, especially external pressures. Limited geographical conditions and also distant areas make the Samin community try hard and optimistic to survive.
\end{abstract}

Keywords: Geographical Influence, Suku Samin, Social Sciences Learning.

\section{A. Pendahuluan}

Masyarakat Samin yang memiliki berbagai tradisi dan budaya bisa dikategorikan sebagai salah satu kelompok etnik yang ada di Indonesia. Komunitas Samin ialah sekelompok orang yang mengikuti ajaran Samin Surosentiko yang muncul pada masa kolonial Belanda. (http://learning-of.slametwidodo.com/).

Samin Surosentiko di usianya yang 31 tahun pada tahun 1890 mulai menyebarkan ajarannya kepada orang-orang sedesanya. Ajarannya mendapat tanggapan baik, dan segera memikat orang banyak dari desa-desa sekitarnya. Semula ajaran itu tidak serta merta menarik minat pemerintah dan tidak juga menimbulkan persoalan bagi pemerintahan kolonial. Namun sekitar tahun 1905 terjadi perubahan, karena para pengikut Samin mulai menarik diri dari kehidupan umum di desanya, menolak memberikan sumbangan pada lumbung desa dan menggembalakan 
ternaknya bersama ternak yang lain. ( Widiyanto, 1983 ). Sehingga pada waktu itu masyarakat Samin dapat diidentifikasikan sebagai masyarakat yang ingin membebaskan dirinya dari ikatan tradisi besar yang dikuasai oleh elit penguasa yaitu pemerintahan kolonial.

Sebagai salah satu kelompok etnik yang ada di Indonesia, masyarakat Samin memiliki nilai-nilai budaya yang berbeda dengan masyarakat lainnya. Selama lebih dari 100 tahun masyarakat Samin sudah mengalami perubahan pada pranata sosial dan kebudayaan yang selama ini mereka anut. (http://learningof.slametwidodo.com/)

Kehidupan masyarakat samin ini dipengaruhi oleh kondisi geografis wilayah tempat mereka tinggal. Hal ini terbukti dengan jenis matapencaharian mereka yang mayoritas adalah sebagai petani dan pencari kayu bakar. Hidupnya yang mengelompok pada kawasan perhutani juga menjadi suatu aspek dimana kondisi geografis sangat mempengaruhi.

Studi ini menggunakan paradigma Interpretif untuk mengungkap kehidupan masyarakat suku samin yang dipengaruhi oleh kondisi geografis. Dimana apa yang diperoleh peneliti dalam penelititan diungkapkan secara mendalam dan menyeluruh. Pendapat serta ungkapan itu sesuai dan berdasar pada kenyataan yang ada.

Dalam Penelitian ini peneliti bermaksud memahami fenomena kehidupan masyarakat suku Samin ditinjau dari kondisi geografis yang berpengaruh terhadap kehidupan sosial masyarakatnya

\section{B. Metode}

Penelitian ini dilakukan pada komunitas Samin Desa Jepang Kecamatan Margomulyo Kabupaten Bojonegoro. Masyarakat setempat dengan pokok aktivitas pencaharian utama sebagai petani. Dipilihnya dusun ini sebagai lokasi dan obyek penelitian ini didasarkan atas pertimbangan : (1) masyarakat di wilayah tersebut masih menjunjung tinggi nilai-nilai budaya Samin; (2) secara geografis wilayah tersebut merupakan wilayah agraris yang berada di kaki Pegunungan Kendeng, yang sangat berperan penting dalam pelestarian lingkungan hidup; (3) secara historis wilayah ini menyimpan banyak tradisi lisan yang termanifestasikan dalam sikap dan perilaku tradisional dan kearifan lokal yang sangat berpengaruh dalam pembentukan kognisi generasi penerusnya.

Dalam penelitian ini, peneliti bermaksud memahami fenomena yang terjadi dalam aktivitas masyarakat Samin khususnya menyangkut strategi bertahan dan strategi adaptasi petani Samin di era global. Fenomena yang ingin dipahami secara mendalam meliputi: strategi bertahan petani Samin dalam menghadapi tekanan, strategi adaptasi petani Samin terhadap perubahan. Berdasarkan masalah yang diajukan dalam penelitian ini, yang lebih menekankan pada masalah proses dan 
makna, maka jenis penelitian yang tepat adalah penelitian kualitatif deskriptif. Jenis penelitian ini akan mampu menangkap berbagai informasi kualitatif dengan deskripsi teliti dan penuh nuansa, yang lebih berharga daripada sekedar pernyataan jumlah ataupun frekuensi dalam bentuk angka (Sutopo, 2002). Bogdan dan Biklen (1982) mengidentifikasi ciri khusus penelitian kualitatif adalah memiliki latar alami sebagai sumber data, peneliti dipandang sebagai instrumen kunci, bersifat deskriptif, lebih mementingkan proses daripada hasil semata, analisis data cenderung secara induktif, dan makna merupakan masalah esensial dalam rancangan penelitian kualitatif. Selanjutnya untuk memahami arti peristiwa, fenomena yang muncul dalam kehidupan sehari-hari dan untuk menginterprestasikan pengalaman-pengalaman dan pengetahuan-pengetahuan mereka dengan orang lain maka pendekatan yang digunakan dalam penelitian ini adalah pendekatanfenomenologis (Moleong, 2000). Sutopo (2002), menekankan dalam penelitian dengan pendekatan fenomenologis, yang utama adalah multiperspektif dan intersubjektif. Multi perspektif dalam arti dengan berbagai cara pandang akan mempertajam dalam menangkap sesuatu yang diteliti. Sedangkan intersubjektif di sini dalam arti berusaha untuk masuk kedalam dunia konseptual para subjek yang ditelitinya sedemikian rupa sehingga mereka mengerti apa dan bagaimana suatu pengertian yang dikembangkan oleh mereka di sekitar peristiwa dalam kehidupan sehari-hari.

Di samping itu, menurut Collin (dalam Basrowi Sukidin, 2002) dengan pendekatan fenomenologis akan mampu mengungkap obyek secara meyakinkan, meskipun obyek itu berupa obyek kognitif maupun tindakan ataupun ucapan. Sedangkan rancangan studi kasus ini termasuk studi kasus tunggal terpancang (Yin, 1987) yaitu dalam penelitian ini peneliti akan memusatkan perhatian pada kasus yang telah ditetapkan dan sesuai dengan fokus penelitian yang telah dirumuskan. Pada tiap kasusnya proses analisisnya akan dilakukan dengan menggunakan model analisis interaktif (Miles dan Huberman dalam Sutopo, 2002). Dalam model analisis ini, tiga komponen analisisnya yaitu : reduksi data, sajian data, dan penarikan simpulan atau verifikasi.

\section{Hasil dan Pembahasan}

\section{KEHIDUPAN MASYARAKAT SUKU SAMIN}

Masyarakat Samin adalah keturunan para pengikut Samin Soerontiko yang mengajarkan sedulur sikep, dimana dia mengobarkan semangat perlawanan terhadap Belanda dalam bentuk lain di luar kekerasan. Sedulur Sikep hidup secara tersebar di pantai utara Jawa Tengah, seperti Kudus, Pati, Blora, Rembang, Bojonegoro bahkan sampai ke Ngawi. 
Samin Soerontiko sering disebut juga sebagai Raden Kohar. Ia masih berdarah bangsawan Majapahit yang hidup pada zaman kolonial Belanda. Karena alasan tertentu memutuskan meninggalkan gemerlap dunia kebangsawanan. Ia mendalami keilmuan spiritual yang saat itu sudah mulai diintervensi oleh kepentingan kelompok tertentu, khususnya oleh agama-agama baru dan tata kehidupan kolonial. Mbah Samin mendalami sendiri nilai-nilai budi luhur serta beladiri menentang penjajahan Belanda dan pada akhirnya mengajarkan kepada murid-muridnya. Begitu mencoloknya sikap Mbah Samin terhadap tata kehidupan saat itu, sehingga sampai kini orang lain mengatakan " Dasar orang Samin" pada tindak-tanduk serupa. (Wahono dkk, 2002)

Bentuk yang dilakukan adalah menolak membayar pajak, menolak segala peraturan yang dibuat pemerintah kolonial. Masyarakat ini acap memusingkan pemerintah Belanda maupun penjajahan Jepang karena sikap itu, sikap yang hingga sekarang dianggap menjengkelkan oleh kelompok diluarnya. Masyarakat Samin sendiri juga mengisolasi diri sehingga baru pada tahun 70an mereka baru tahu Indonesia telah merdeka. .(http://rinangxu.wordpress.com/2006/12/07/samin-anarchy-rebel-budaya/)

Orang luar Samin sering menganggap mereka sebagai kelompok yang lugu, suka mencuri, menolak membayar pajak, dan acap menjadi bahan lelucon terutama di kalangan masyarakat Bojonegoro. Pokok ajaran Samin diantaranya adalah :

1. Agama adalah senjata atau pegangan hidup. Paham Samin tidak membeda-bedakan agama, yang penting adalah tabiat dalam hidupnya.

2. Jangan mengganggu orang, jangan bertengkar, jangan irihati dan jangan suka mengambil milik orang lain.

3. Bersikap sabar dan jangan sombong.

4. Manusia harus memahami kehidupannya, sebab roh hanya satu dan dibawa abadi selamanya.

5. Bila orang berbicara, harus bisa menjaga mulut, jujur dan saling menghormati. Orang Samin dilarang berdagang karena terdapat unsur 'ketidakjujuran' didalamnya. Juga tidak boleh menerima sumbangan dalam bentuk apapun.

Masyarakat Samin terkesan lugu, bahkan lugu yang amat sangat, berbicara apa adanya, dan tidak mengenal batas halus kasar dalam berbahasa karena bagi mereka tindak-tanduk orang jauh lebih penting daripada halusnya tutur kata. Kelompok ini terbagi dua, yakni Jomblo-ito atau Samin Lugu, dan Samin sangkak, yang mempunyai sikap melawan dan pemberani. Kelompok ini mudah curiga pada pendatang dan suka membantah dengan cara yang tidak masuk akal. Ini yang sering menjadi stereotip dikalangan masyarakat Bojonegoro dan Blora. Mereka melaksanakan pernikahan secara langsung, tanpa melibatkan lembaga-lembaga pemerintah bahkan agama, karena agama mereka tidak diakui negara. Mereka menganggap agamanya sebagai Agama Adam, yang diterapkan turun temurun. Dalam buku Rich Forests, Poor People - Resource 
Control and Resistance in Java, Nancy Lee Peluso menjelaskan para pemimpin samin adalah guru tanpa buku, pengikut-pengikutnya tidak dapat membaca ataupun menulis. Suripan Sadi Hutomo dalam Tradisi dari Blora (1996) menunjuk dua tempat penting dalam pergerakan Samin: Desa Klopodhuwur di Blora sebelah selatan sebagai tempat bersemayam Samin Surosentiko, dan Desa Tapelan di Kecamatan Ngraho, Bojonegoro, yang memiliki jumlah terbanyak pengikut Samin. Mengutip karya Harry J. Benda dan Lance Castles (1960), Suripan menyebutkan, orang Samin di Tapelan memeluk saminisme sejak tahun 1890. Dalam Encyclopaedie van Nederlandsch Indie (1919) diterangkan, orang Samin seluruhnya berjumlah 2.300 orang (menurut Darmo Subekti dalam makalah Tradisi Lisan Pergerakan Samin, Legitimasi Arus Bawah Menentang Penjajah, 1999, jumlahnya 2.305 keluarga sampai tahun 1917, tersebar di Blora, Bojonegoro, Pati, Rembang, Kudus, Madiun, Sragen, dan Grobogan) dan yang terbanyak di Tapelan. (http://rinangxu.wordpress.com/2006/12/07/samin-anarchy-rebelbudaya/)

Sebagai gerakan yang cukup besar saminisme tumbuh sebagai perjuangan melawan kesewenangan Belanda yang merampas tanah-tanah dan digunakan untuk perluasan hutan jati pada zaman penjajahan di Indonesia. Sekitar tahun 1900, mandor hutan yang menjadi antek Belanda mulai menerapkan pembatasan bagi masyarakat dalam soal pemanfaatan hutan. Para mandor itu berbicara soal hukum, peraturan, serta hukuman bagi yang melanggar. Tapi para saminis, atau pengikut Samin, menganggap remeh perkara itu. Sosialisasi hukum itu lantas ditindaklanjuti pemerintah Belanda dengan pemungutan pajak untuk air, tanah, dan usaha ternak mereka. Pengambilan kayu dari hutan harus seizin mandor polisi hutan. Pemerintah Belanda berdalih semua pajak itu kelak dipakai untuk meningkatkan kesejahteraan rakyat. Akal bulus itu ditentang oleh masyarakat pinggir hutan di bawah komando. Samin Surosentiko yang diangkat oleh pengikutnya sebagai pemimpin informal tanpa persetujuan dirinya. Oleh para pengikutnya Samin Surosentiko dianggap sebagai Ratu Tanah Jawi atau Ratu Adil Heru Cakra dengan gelar Prabu Panembahan Suryangalam. Para pengikut Samin berpendapat, langkah swastanisasi kehutanan tahun 1875 yang mengambil alih tanahtanah kerajaan menyengsarakan masyarakat dan membuat mereka terusir dari tanah leluhurnya.

Sebelumnya, pemahaman pengikut Samin adalah: tanah dan udara adalah hak milik komunal yang merupakan perwujudan kekuasaan Tuhan Yang Maha Esa. Mereka menolak berbicara dengan mandor-mandor hutan dan para pengelola dengan bahasa krama. Sebagai gantinya para saminis memperjuangkan hak-haknya dalam satu bingkai, menggunakan bahasa yang sama, Jawa ngoko yang kasar alias tidak taklim. Sasaran mereka sangat jelas, para mandor hutan dan pejabat pemerintah Belanda. Ketika mandor hutan menarik pajak tanah, secara demonstratif mereka berbaring di tengah tanah 
pekarangannya sambil berteriak keras, "Kanggo!" (punya saya). Ini membuat para penguasa dan orang-orang kota menjadi sinis dan mengkonotasikan pergerakan tersebut sebagai sekadar perkumpulan orang tidak santun. Penguasa bahkan mendramatisasikan dengan falsafah Jawa kuno yang menyatakan "Wong ora bisa basa" atau dianggap tak beradab. Akibatnya, para pengikut Samin yang kemudian disebut orang Samin, dicemooh dan dikucilkan dari pergaulan. Ketika pergerakan itu memanas dan mulai menyebar di sekitar tahun 1905, pemerintah Belanda melakukan represi. Menangkap para pemimpin pergerakan Samin, juga mengasingkannya. Belanda juga mengambil alih tanah kepemilikan dari mereka yang tak mau membayar pajak. Namun tindakan pengasingan dan tuduhan gerakan subversif gagal menghentikan aktivitas para saminis. Sekarang pun sisa-sisa para pengikut Samin masih ditemukan di kawasan Blora yang merupakan jantung hutan jati di P. Jawa.

(http://rinangxu.wordpress.com/2006/12/07/samin-anarchy-rebel-budaya/)

\section{PENGARUH KONDISI GEOGRAFIS TERHADAP KEHIDUPAN SOSIAL MASYARAKAT SAMIN}

Dusun Jepang, salah satu dusun dari 9 dusun di Desa Margomulyo yang berada di kawasan hutan memiliki luas 74,733 hektar. Jarak sekitar 4,5 kilometer dari ibu kota Kecamatan Margomulyo, 69 kilometer arah barat-selatan atau kurang lebih dengan jarak tempuh antara 2-2,5 jam perjalanan dengan kendaraan dari ibu kota Bojonegoro dan 259 kilometer dari ibu kota Provinsi Jawa Timur (Surabaya). Dusun jepang merupakan kawasan hutan lindung milik perhutani dimana berada di lembah bengawan solo yang kering. Sehingga untuk pertanian produktifnyapun relatif sedikit.

Dari keadaan konsisi geografis desa jepang ini menjadikan masyarakat samin mempunyai cara yang berbeda dalam kehidupan masyarakatnya. Kemampuan masyarakat Samin untuk berinteraksi dengan lingkungan dan alam patut untuk di apresiasi. Masyarakat Samin dalam perkembangannya telah melalui berbagai macam tekanan terutama tekanan yang bersifat eksternal. Dahulu tekanan berasal dari penjajahan kolonial Belanda dan saat ini adalahmasuknya nilai-nilai modernitas (infiltrasi kapitalisme). Namun dalam hal ini masyarakat Samin melakukan adaptasi dengan melawansecara pasif sebagai bentuk adapatasi sehingga mereka tetap mempertahankan dan berjalan pada cara hidup yang telah mereka anut dari dulu.

Menurut Vayda dan Rappaport dalam Mulyadi (2007), adaptasi manusia dapat dilihat secara fungsional dan prosesual. Adaptasi fungsional merupakan respons suatu organism atau sistem yang bertujuan untuk mempertahankan kondisi stabil (homostatis). Sumberdaya lahan (natural resources) masyarakat Samin yang tidak memadai akan mempengaruhi dasar dari sumber nafkah rumahtangganya. Kondisi ini akan menyebabkan munculnya respon bagi masyarakat Samin dan upaya untuk mengadaptasikan diri terhadap krisis. Mereka tidak lagi hanya bisa mengandalkan 
pertanian, mereka juga beralih menjadi pencari ikan-ikan di sungai sungai untuk sekedar bisa tetap mempertahankan hidup. Baginya, keberadaan sungai adalah milik umum yang digunakan untuk kebutuhan semua orang, dan mereka yakin hal tersebut tidak bertentangan dengan ajaran yang mereka anut.

Profesi lain yang berkembang adalah menjadi pengrajin (anyaman bambu, tukang kayu). Kegiatan ini dilakukan di sela-sela melakukuan budidaya pertanian. Mereka tidak bisa lagi menerapkan strategi yang umum dilakukan oleh masyarakat pedesaan pada umumnya, dimana masyarakat tersebut melakukan strategi penghematan konsumsi dan maksimalisasi tenaga kerja keluarga. Hal ini karena masyarakat Samin sudah melakukan kedua hal tersebut.

Masyarakat Samin tidak mau dikatakan orang pemalas, mereka selalu bekerja giat untuk bisa tetap bertahan hidup. Mereka selalu berpedoman pada ajaran "sabar trokal, sabaré diéling-éling, trokalé dilakoni" (kerjakan sikap sabar dan giat, selalu ingat tentang kesabaran dan selalu giat dalam kehidupan). Untuk mencapai kesempurnaan hidup, maka wong urip kudu ngerti uripé, manusia harus mengetahui hakikat kehidupan. Sedangkan adaptasi prosesual merupakan sistem tingkah laku yang dibentuk sebagai akibat dari proses penyesuaian manusia terhadap perubahan-perubahan lingkungan disekitarnya. Perubahan-perubahan lingkungan yang sangat berpengaruh terhadap proses adaptasi adalah perubahan lingkungan yang berupa bencana. Pola tanam padi diganti palawija karena kekurangan air sebagai akibat dari ketridakseimbangan ekosistem hutan.

Strategi adaptasi lain, dilakukan dengan menciptakan, mengembangkan dan memelihara hubungan-hubungan sosial yang telah membentuk suatu jaringan sosial. Fungsi jaringan sosial adalah untuk memudahkan anggota-anggotanya memperoleh akses ke sumber daya ekonomi yang tersedia dilingkungannya. Jaringan sosial dapat dibentuk berdasarkan basis kerabat, tetangga, pertemanan, atau campuran dari unsur-unsur tersebut.

Russel Bernard (dalam Rudito, B dan Melia,F., 2008), menggambarkan jaringan sosial sebagai sebuah kotak yang isinya mengandung berbagai bentuk jaringan. Secara garis besar ada dua jenis tipe jaringan sosial, yaitu atribut dan transaksional. Dikatakan, 'jaringan antar individu dalam komunitas yang sudah ditentukan berdasarkan atributatribut yang melekat pada setiap orang dalam komunitas tersebut. Misalnya jenis kelamin, atribut sosial dan keluarga. Pertukaran yang terjadi dalam komunitas, ibarat 'tukaran barang', dilihat sebagai konsekuensi dari atribut yang dikenakan oleh individuindividu tersebut. 


\section{Simpulan}

Dari penelitian ini dapat disimpulkan bahwa Kondisi geografis membentuk karakter orang Samin yang sederhana tetapi pekerja keras, khususnya di bidang pertanian. Orang Samin juga dikenal berbicara seperlunya saja. Kebersahajaan yang disertai karakter pekerja keras itu menyebabkan derajad kemandirian orang Samin sangat tinggi. Sebagai suatu komunitas, mereka menggali potensi desanya sebagai landasan untuk berkembang, seraya menghindari diri menerima bantuan dan ketergantungan terhadap orang luar.

Bagi orang Samin, musuh kemandirian adalah: sifat malas, ketidakberdayaan menghadapi sebuah situasi yang sulit, dan kecerobohan perorangan. Masyarakat Samin memiliki keteguhan yang kuat dalam bertindak, memiliki strategistrategi tersendiri dalam menghadapi dunia luar yang akan menghancurkan nilai-nilai budaya lokal yang merupakan warisan dari leluhurnya. Untuk itu kiranya masyarakat lain bisa belajar pada masyarakat Samin untuk tetap menjaga harkat dan martabatnya yang tercermin dalam kemandirian lokal. Salah satu karakter yang ditonjolkan oleh masyarakat Samin adalah kolektivisme yang kuat baik dalam tataran keluarga maupun dan masyarakat.

\section{Daftar Rujukan}

Basrowi Sukidin, 2002. Metode Penelitian Kualitatif : Perspektif Mikro. Surabaya: Insan Cendikia

Bogdan dan Biklen, 1982. Qualitative Research for Education. United States of America: Mc Graw-Hill, Inc.

Fukuyama, 1992. The End of History and The Last Man. Dalam Mohammad Husein Amrullah (Penerjemah). Yogyakarta :Penerbit Qalam.

Hendropuspito, D., OC. 1989. Sosiologi Sistematik. Yogyakarta: Penerbit Kanisius.

Ife, Jime. 1995. Community Development : Creating Community AlternativesVision, Analiysis and practice.Melbourne : Longman.

International Forum on Globalization, 2001. Globalisasi, Kemiskinan dan Ketimpangan. Yogyakarta : Cindelaras Pustaka Rakyat Cerdas.

Korten, D,. 1984. Pembangunan Yang Memihak Rakyat : Kupasan Tentang Teori dan Metode Pembangunan. Lembaga Studi Pembangunan. Jakarta.

Legawa, 1999. Subak - Organisasi Sosio-Religius di Bali. Dalam Kusnaka

Adimiharja (Editor). Petani Merajut Tradisi Era Globalisasi - Pemberdayaan Sistem Pengetahuan Lokal dalam Pembangunan. Bandung : Humaniora Utama Press.

Moleong, Lexy, J., 2000. Metodologi Penelitian Kualitatif. Bandung : PT Remaja Rosdakarya.

Mumfangati, dkk., 2004. Kearifan Lokal di Lingkungan Masyarakat Samin Kabupaten Bilora. Propinsi Jawa Tengah. Kementrian Kebudayaan dan Pariwisata Deputi 
Bidang Pelestarian dan Pengembangan Kebudayaan Balai Kajian Sejarah dan Nilai Tradisional Yogyakarta Proyek Pemanfaatan Kebudayaan Daerah.

Scott, James C. 1976. The Moral Economy of The Peasant: Subsistance and Rebbelion in Southeast Asia. New Haven : Yale University Press.

Suripan Sadi Hutomo, 1996. Tradisi dari Blora. Semarang : Citra Almamater.

Sutopo, 2002. Metodologi Penelitian Kualitatif : Dasar Teori dan Terapannya dalam Penelitian. Surakarta : Sebelas Maret University.

Yin, R.K. 1987. Case Study Research : Design and Methods. Beverly Hills. California : Sage Publication. 